\title{
The Ex-Dividend-Day Price Behaviour of Blue-Chip Stocks: International Evidence
}

\author{
Anders Isaksson Ph.D. \\ Assistant Professor, Umeå School of Business and Economics \\ Umeå University, 90187 Umeå, Sweden \\ Tel: 46-90-786-7879Ｅ-mail: anders.isaksson@usbe.umu.se
}

Md Mohibul Islam

Lecturer, University of Liberal Arts Bangladesh

E-mail: mohibul00@yahoo.com

Received: June 14, 2012 Accepted: January 25, $2013 \quad$ Published: June 1, 2013

doi:10.5296/ajfa.v5i1.1948ＵRL: http://dx.doi.org/10.5296/ajfa.v5i1.1948

\begin{abstract}
To explain the ex-day stock price behaviour, previous research has mostly focused on dividend yield and expected return. Most of these studies concentrated on the US markets and were conducted in a stable economic condition. This paper examines the most liquid common stock (blue-chip) prices behaviour on the ex-day in a period of financial crisis and covers four major capital markets from different geographic locations (the US, the UK, Japan, and China). On the New York and Shanghai Stock Exchanges, we observe that the stock prices drop does not differ from the dividend amount on the ex-dividend day and there is no evidence of abnormal return and short-term trading. On the Tokyo Stock Exchange, the stock prices fall less than the dividend amount, which is in contrast to the London Stock Exchange, where the stock prices fall more than the dividend amount. On the Tokyo and London Stock Exchanges, we observe abnormal return and short-term trading around the ex-day. Possible explanations for these differences can be financial crisis (in the UK) and short-term trading (in the Japan)
\end{abstract}

Keywords: Ex-dividend day; abnormal return; short-term trading; blue-chip stocks; arbitrage opportunity

JEL Classification: G14; G15; G35 


\section{Introduction}

In a market with no transaction costs and no taxes, the stock prices should drop by the same amount as the dividend paid on the ex-dividend day (Campbell and Beranek, 1955; Elton and Gruber, 1970). However, more than fifty years of research have concluded that the stock price drop differs from the dividend amount on the ex-dividend day. Several types of interpretations are advanced in the literature to explain such behaviour. Among all these studies, the most pronounced rationales are (i) the tax explanation (Elton and Gruber, 1970; Litzenberger and Ramaswamy, 1979; Poterba and Summers, 1984; Barclay, 1987; Lasfer, 1995; Bell and Jenkinson, 2002; Lasfer and Zenonos, 2003; Chen et al. 2011); (ii) the cost of trading as well as the associated risk (Kalay, 1982; Heath and Jarrow, 1988; Lakonishok and Vermaelen, 1986; Boyd and Jagannathan, 1994; Michaely and Vila, 1996); and (iii) the market microstructure (Frank and Jagannathan, 1998; Bali and Hite, 1998).

If the stock prices drop differs from the dividend amount, it signals the inefficiency of a capital market. Short-term investors would be interested in such inefficiency of the market (those who buy and sell stocks in a short run and try to make a profit by using the inefficiency of a market) to make an arbitrage profit.

Elton and Gruber (1970), Litzenberger and Ramaswamy (1979), Poterba and Summers (1984), and Barclay (1987) pointed out a strong positive relationship between the dividend yield and the expected return. Lasfer and Zenonos (2003) examined the stock price behaviour on the European markets (France, Germany, the UK, and Italy). Most of these studies focused on the dividend yield and the entire stock market. Study observed mean drop of stock prices on the New York Stock Exchange is 0.7767 which is due to the higher taxation on dividend income than capital gain (Elton and Gruber, 1970). Similarly, further tax evidence has been observed on the Chinese Stock Exchange for the large dividend yield stocks (Nikolaos et al., 2006) and London Stock Exchange (Lasfer and Zenonos, 2003, mean price drop 0.701). Furthermore, insignificant evidence of tax hypothesis has been observed on the Tokyo Stock Exchange (Kato and Lowenstein, 1995) where ex-day stock prices (mean drop of stock prices is -0.9317) are influnced by the year end effect. However, no study has concentrated on the liquidity of the stocks and the quality of information available to the investors and market makers to adjust the stock prices. Furthermore, no single study has compared four key capital markets which represent three major geographic locations (Asia, Europe and America). This study concentrates on the most liquid common stocks, known as the blue chips of a stock market. Secondly, the aim of this study is to explain the ex-day stock price behaviour of four major stock markets which represent three different geographic locations and very dissimilar market structures (different tax codes and trading rules and legislation). The reason why we choose these four capital markets is because these markets represent maximum market capital in Asia, Europe and America and the indexes are the key indicators for an investment decision to any investors.

Blue-chip indexes are chosen because they hold the most important stocks of a certain market which are preferred by the investors. Blue-chip stocks represent maximum market capital and function as a benchmark of the market movements (downside or upside). Blue-chip indexes 
have been proven to be an efficient empirical proxy for all-shares market indexes (Annaert et al., 2011). Investors are well aware of the market information of these stocks and, along with the market makers, continuously adjust valuation models. By focusing on only the largest stocks we avoid potential small firms effects, e.g. effects lack of liquidity or infrequent trading (Franks et al. 2009; Amihud \& Mendelson, 2012; Roll, 2012) or other firm size effects (Chan, Chen, \& Hsieh, 1985). This paper also limits the market inefficiency by choosing most liquid common stocks as liquidity of stocks facilities market efficiency (Fowler and Gottesman 2000; Jones, 2001; Amihud, 2002; Tarun et al., 2008). Secondly, we examine abnormal return and relative trading volume to find out the relevancy of arbitrage opportunity, which might exist on the ex-dividend day (due to the fact that the stock price drop differs from the dividend amount).

\section{Prior research of stock price behaviour on the ex-dividend day}

The oldest study of stock price behaviour on the ex-dividend day was by Campbell and Beranek (1955), in which they argued that the stock prices drop less than the dividend amount. However, the debate on the stock price drop (it is expected that the drop in stock prices is equal to the dividend amount) on the ex-day and the rationale behind it became widespread after the publication of Elton and Gruber (1970). Their paper suggested that the stock prices fall less than the dividend amount on the ex-dividend day due to the effect of taxation. Moreover, their findings explained that the investors who are in higher tax brackets are interested in lower dividend yields, whereas lower-tax-bracket investors prefer the opposite. Litzenberger and Ramaswamy (1979), Poterba and Summers (1984), Barclay (1987), and Whitworth and Rao (2010) also concluded there was significant evidence of clientele effect.

Kalay (1982) was the first researcher who challenged the tax hypothesis as a cause of differentiation in price drop on the ex-day. He supported short-term trading and transaction costs. A recent study by Bali and Francis (2011) also argued in favour of transaction cost and explained that tax can be a component which can affect the investors' investment decision but cannot influence the ex-day stock prices. Heath and Jarrow (1988) expounded that the actual ex-day price drop is unknown and short-term trading around the ex-day is risky and this risk is not trivial (Michaely and Vila, 1996). Heath and Jarrow's research (1988) also implied that ex-dividend-day returns must include a risk premium. For instance, Boyd and Jagannathan (1994) added a risk premium to the discount rate when they modelled the ex-dividend-day return.

Kato and Lowenstein (1995) focused on the Japanese market, where investors have no difference in taxation concerning either short-term or long-term trading. According to them, Japanese industry is unique ('Most of the Japanese firms are affiliated with different business groups, or keiretsu, and engage themselves in trading and reciprocal shareholding', p. 818) and likely to be influenced by the corporate traders. Their study supported short-term trading. Lasfer's study (1995) was on the UK market and presented the effect of the changes before and after the Income and Corporation Taxes Act 1988. His model concluded a significant positive return on stock prices before 1988 due to the differentiation in taxation (both on 
capital gain and dividend). Additionally, the model presented an insignificant return after 1988, when there is no significant difference in taxation laws regarding both dividend and capital gain. Finally, he argued that dividend yield and the duration of the settlement period generate a positive return on the ex-day, not the bid-ask-spread, transaction costs, short-term trading, or other means of dividend distribution strategies. Nikolaos et al. (2006) suggested that the price drop for taxable dividend is more than the dividend amount if the taxation on dividend is higher than the capital gain. Their paper is based on the behaviour of common stocks on the Chinese Stock Exchange and they focused on both taxable and non-taxable cash dividend.

Booth and Johnston (1984) introduced an institutional and a professional short-term-trading hypothesis. These two hypotheses differ regarding tax treatment. They found that the ex-dividend day is an important input in the trading strategy for investors and traders (i.e. the market makers). Shantanu et al. (2004) found strong evidence of short-term trading around the ex-dividend day and pressure on the short-term trader to buy before the event date and sell afterwards. They re-examined the behaviour of stock prices and the volume of all listed companies on the Canadian stock market from 1996 to 2003. Short-term trading is also supported by Eades et al. (1984); Lakonishok and Vermaelen (1986); and Naranjo et al. (2000) for higher yield stocks.

David and Jarrow (1988) performed their study based on two assets, risky stocks and riskless bonds, to find the possible arbitrage opportunity on the ex-dividend day. They argued that although the stock price drop differs from the dividend amount, no trading strategies can generate any arbitrage profit. Dai and Rydqvist (2009) investigated the arbitrage opportunity around the ex-dividend day on the Norwegian stock market. They explained that the arbitrageur cannot predict the step-up amount, which takes one year to complete after the trade. The study introduced a risk of miscalculating the actual step-up amount, but there is a possibility of diversifying it. They also concluded that the uncertainty about the future cash flow can prevent arbitrage opportunities. Elton et al. (1984); Kalay (1984); and Lakonishok and Vermaelen (1986) explained the possibility of an arbitrage opportunity based on a short-term-trading hypothesis. They concluded that although an arbitrage opportunity exists, it is not possible to seize that opportunity because of transaction costs.

\section{Methodology}

The objective of this study is to examine the ex-day stock (blue-chip) price behaviour. In general, before the ex-dividend day, an individual investor has two choices (no short-selling, call-option, or put-option strategy):

1. Hold the stocks on the cum-day and receive dividend as income.

2. Sell the stocks on the cum-day and receive the share value.

If an investor chooses to sell his/her share on the cum-day, he/she will receive only stock prices and lose the claim on the dividend. Under this assumption, an investor does not need to wait for the dividend payments. On the other hand, if an investor chooses to keep the stock on the cum-day (assuming that other market or unsystematic influences are constant and there is 
no effect of taxes), then he/she is entitled to receive the total wealth, which is equal to the stock prices plus the dividend amount.

Let

$P_{O}=$ stock price on the ex-dividend day

$P_{-1}=$ stock price on the cum-dividend day

$D=$ dividend amount

If an investor holds the stocks on the cum-dividend day, he/she will receive stock prices plus the dividend amount, which is expressed as

$$
P_{-1}=P_{O}+D
$$

If we deduct ' $P_{O}$, from both sides of the equation (1) and divide the remaining value by the dividend ' $D$ ', we receive (equation 2)

$$
R P R=\frac{P_{-1}-P_{O}}{D}=\left(\frac{P_{O}+D-P_{O}}{D}\right)=1
$$

This ratio is known as the raw price ratio (RPR), which explains the price changes from the cum-dividend day to the ex-dividend day. This ratio illustrates the changes based on the amount of dividend paid out on the ex-day. The null hypothesis H1 is developed from the equation (2), which is

H1: the mean (median) of the RPR $=1$

Hyptotheis 1 states that stock prices should drop by the same amount as the dividend paid on the ex-day. One criticism of this ratio is that the RPR is subject to the market influence from the cum-dividend day to the ex-dividend day. To adjust this bias, we computed the market-adjusted price ratio (MAPR). $R_{m}$ is the return of the market index. The value of the MAPR is equal to the cum-dividend-day stock price minus the discounted (by daily market return) ex-day price, which is divided by the dividend amount. The MAPR is expressed as

$$
M A P R=\frac{P_{-1}-\frac{P_{O}}{1+R_{m}}}{D}
$$

The hypothesis $\mathrm{H} 2$ is developed from the equation (3), which is expressed as 


\section{Mll Macrothink}

H2: the mean (median) of the MAPR $=1$

Hyptotheis 2 states that the drop of stock prices should be equal to the dividend amount after adjusting the market influences (if any) to determine the daily stock prices. We also compute the raw price drop (RPD) ratio

$$
R P D=\frac{P_{-1}-P_{O}}{P_{-1}}
$$

The theoretical value of the RPD is equal to the dividend yield, which is expressed as

H3: the mean (median) of the RPD = dividend yield

And the market-adjusted price drop (MAPD) ratio

$$
M A P D=\frac{\left(P_{-1}-\frac{P_{O}}{1+R_{m}}\right)}{P_{-1}}
$$

The theoretical value of the MAPD is also equal to the dividend yield and it is expressed as

H4: the mean (median) of the MAPD = dividend yield

H3 and H4 illustrate that mean (median) raw price drop and market-adjusted price drop of each stock should be equal to their dividend yield.

In addition, we compute the dividend yield, $d$

$$
d=\frac{D}{P_{-1}}
$$

The raw ex-dividend-day return, $R_{O}$

$$
R_{O}=\frac{P_{O}-P_{-1}+D}{P_{-1}}
$$

And the market-adjusted ex-dividend-day abnormal return, $M A A R$

$$
M A A R=R_{O}-R_{m}
$$

The null hypothesis H5 is developed from the equation (8), which is true if the value of the MAAR is equal to 0 . The hypothesis $\mathrm{H} 5$ is expressed as

H5: the mean (median) of the MAAR $=0$ 


\section{Macrothink}

During the ex-day trading, stocks cannot have abnormal return (after adjusting market influences) and it should be zero which is demonstrated in H5. Furthermore, we compute the relative trading volume ( $\mathrm{RTVt}$ ) for the day ' $\mathrm{t}$ ' around the ex-dividend day ( $\mathrm{t}=-5$ to +5 )

$$
R T V_{t}=\frac{V_{i t}}{A V T V_{i}}
$$

where

$V_{i t}=$ the trading volume on the day ' $\mathrm{t}$ ' for the stocks ' $\mathrm{i}$ ' and

$A V T V_{i}=$ the average trading volume of a company ' $\mathrm{i}$ ' estimated over the period of -30 to -5 and +5 days relative to the ex-dividend day.

The theoretical value of the RTV is equal to 1 and it is expressed as

H6: ${ }^{R T V_{t}}$ (relative trading volume) $=1$

H6 illustrates the level of significance of an investor to trade around the ex-day to grab the abnormal return (if any).

\subsection{Data collection}

The data we collected to examine the stock price behaviour on the ex-dividend day covers the fiscal years 2005 to 2009. We selected companies from the New York Stock Exchange (NYSE), Tokyo Stock Exchange (TSE), Shanghai Stock Exchange (SSE), and London Stock Exchange (LSE). As a proxy for blue-chip stock (Weiss and Lowe, 1988; Cho and Engle, 1999; Hearn, 2010), our sample of companies was selected to meet these specific criteria:

- $\quad$ Listed under the S\&P 100 index, TOPIX 100 index, SSE 180 index, or FTSE 100 index.

- $\quad$ Should have paid a cash dividend.

- Stock prices must be available thirty-five days prior to, and five days after, the ex-dividend day.

Our final sample consisted of 1,733 observations from the NYSE, 951 from the TSE, 887 from the SSE, and 1,106 from the LSE.

From Thomson Reuters Datastream, we collected daily stock prices, daily trading volumes, cash dividend amounts, cum- and ex-dividend dates, and the annual market capital of each company. Finally, we compiled daily index prices (S\&P 100, TOPIX 100, SSE 180, and FTSE 100) from the same Thomson Reuters Datastream.

\section{Empirical findings and analysis}

Table 1 shows the theoretical (hypothesized value) mean and median values of the RPR, 
MAPR, RPD, MAPD, MAAR, and RTV of the NYSE, TSE, SSE, and LSE. A t-statistic is used to analyse the differences between the theoretical and mean values. Additionally, the Wilcoxon signed-rank test is used to examine the differences between the median and corresponding theoretical values. A t-test is also used to compute the MAAR.

Table 1. Theoretical values of the RPR, MAPR, RPD, MAPD, MAAR, RTV (-1 to -5$)$, and RTV (1 to 5) of the NYSE, TSE, SSE, and LSE

\begin{tabular}{lllllllll}
\hline & \multicolumn{3}{l}{ Theoretical values } & & & & & \\
& NYSE & \multicolumn{2}{l}{ TSE } & & SSE & & LSE & \\
\cline { 2 - 9 } & Mean & Median & Mean & Median & Mean & Median & Mean & Median \\
\hline RPR & 1 & 1 & 1 & 1 & 1 & 1 & 1 & 1 \\
MAPR & 1 & 1 & 1 & 1 & 1 & 1 & 1 & 1 \\
RPD & 0.0069 & 0.0062 & 0.0084 & 0.0074 & 0.0162 & 0.0123 & 0.0121 & 0.01 \\
MAPD & 0.0069 & 0.0062 & 0.0084 & 0.0074 & 0.0162 & 0.0123 & 0.0121 & 0.01 \\
MAAR & 0 & 0 & 0 & 0 & 0 & 0 & 0 & 0 \\
RTV(-1 to -5) & 1 & 1 & 1 & 1 & 1 & 1 & 1 & 1 \\
RTV (1 to 5) & 1 & 1 & 1 & 1 & 1 & 1 & 1 & 1 \\
\hline
\end{tabular}

\subsection{New York Stock Exchange}

Table 2. Mean, median, t-test, and Wilcoxon signed-rank test (z-value) values of the RPR, MAPR, RPD, and MAPD of the NYSE

\begin{tabular}{lccccc}
\hline & Mean & $\begin{array}{c}\text { T-test } \\
\text { (mean) }\end{array}$ & Median & Z-value (median) & Standard deviation \\
\hline RPR & 1.0514 & 0.3204 & 0.9016 & 0.694 & 3.7349 \\
MAPR & 1.0073 & 0.0435 & 0.8788 & 0.407 & 3.9322 \\
RPD & 0.0073 & 0.4563 & 0.0065 & 0.642 & 0.0183 \\
MAPD & 0.0077 & 0.9564 & 0.0066 & 0.512 & 0.0185 \\
Dividend yield & 0.0069 & & 0.0062 & & 0.004 \\
\hline
\end{tabular}

The mean (median) value of the RPR and the associated t-statistic (z-value) suggests that there are no statistical differences between the mean (median) and corresponding theoretical value 1.00 (1.00). The mean (median) of the MAPR and the related t-value (z-value) also shows insignificant differences between the mean (median) and theoretical value 1.00 (1.00). These results argue that stock prices drop by the same amount as the dividend paid on the ex-day. The mean (median) of the RPD ratio, MAPD ratio, and associated t-values (z-value) also suggests that stock prices drop by the same amount as the dividend paid. The findings 
also contend that there is no significant (p-value: 0.362. See Table I in Appendix) MAAR and thus no evidence of short-term trading (before the ex-day, the p-value of the RTV is 0.300 , and afterwards it is 0.197. See Table I in Appendix) before and after the ex-date.

This study is generally inconsistent with Campbell and Beranek (1955) and Elton and Gruber (1970) (they documented that stock prices fall less than the dividend amount) but agrees with Barclay (1987) (the pre-tax-period stock price drop is equal to the dividend amount). Our findings are also inconsistent with Fedenia and Grammatikos (1991) and Lamdin and Hiemstra (1993), who argued that equal taxation on dividend and capital gain for the individual investor reduces the price-drop ratio but does not eliminate it. A similar outcome was also concluded by Cloyd and Weaver (2006).

\subsection{Tokyo Stock Exchange}

Table 3. Observes the mean, median, t-test, and Wilcoxon signed-rank test (z-value) values of the RPR, MAPR, RPD, and MAPD from the TSE

\begin{tabular}{llllll}
\hline & Mean & T-test (mean) & Median & $\begin{array}{l}\text { Z-value } \\
\text { (median) }\end{array}$ & Standard deviation \\
\hline RPR & 0.3927 & -3.0582 & 0.7044 & 0.005 & 3.3465 \\
MAPR & 0.4147 & -2.9328 & 0.7071 & 0.007 & 3.3633 \\
RPD & 0.0054 & -2.6566 & 0.006 & 0.056 & 0.0185 \\
MAPD & 0.0056 & -2.4838 & 0.0061 & 0.067 & 0.0188 \\
Dividend yield & 0.0084 & & 0.0074 & & 0.005 \\
\hline
\end{tabular}

On the TSE, the mean (median) of the RPR and MAPR (see Table 3) and associated t-test (z-value) shows significant statistical differences between the mean (median) and corresponding theoretical value 1.00 (1.00). The values of the RPR and MAPR suggest that the stock price drop is less than the dividend amount on the ex-day. The median values (0.0560 and 0.0670 ) of the RPD and MAPD indicate no significant differences (in the borderline of the 0.05 level) between the observe and theoretical values. However, the t-values (-2.6566 and -2.4838) rejected the null hypothesis. The RPD and MAPD are less than the dividend yield, which also supports that the price drop is less than the dividend amount.

The value of the MAAR (p-value: 0.000. See Table I in Appendix) suggests significant differences from its theoretical value, which is an indication of abnormal return around the ex-dividend day. The result of the RTV supports (p-value: 0.008) short-term trading before the ex-dividend day. However, there is no evidence (p-value: 0.270 ) of short-term trading after the ex-dividend day. Findings suggests that the stock prices drop less than the dividend amount is due the noise traders who work as a proxy in an efficient market to determine the true prices which is also supported by Paul (2006). Our result is inconsistent with Kato and Lowenstein (1995), whose study concluded that the stock prices rise on the ex-day. However, 
our study is consistent with Dhatt et al. (1994), who argued the existence of excess return around the ex-day in Japan.

\subsection{Shanghai Stock Exchange}

Table 4. Observes the mean, median, t-test, and Wilcoxon signed-rank test (z-value) values of the RPR, MAPR, RPD, and MAPD from the SSE

\begin{tabular}{llllll}
\hline & Mean & T-test (mean) & Median & Z-value (median) & Standard deviation \\
\hline RPR & 0.9117 & -0.2538 & 0.94 & 0.858 & 4.102 \\
MAPR & 0.966 & -0.0988 & 0.9249 & 0.906 & 4.0599 \\
RPD & 0.0174 & 0.4375 & 0.0175 & 0.039 & 0.0319 \\
MAPD & 0.0178 & 0.5576 & 0.0171 & 0.036 & 0.032 \\
Dividend yield & 0.0162 & & 0.0123 & & 0.0136 \\
\hline
\end{tabular}

The mean (median) values of the RPR and MAPR (see Table 4) and associated t-statistic (z-value) demonstrate no statistical differences between the mean (median) and theoretical values. These results argue that on the SSE, stock prices drop by the same amount as the dividend paid on the ex-dividend day. The findings for the RPR and MAPR are also explainable by the RPD and MAPD. The mean (median) values of the RPD and MAPD and related t-values (z-values) show no statistical differences between the mean (median) and theoretical values (dividend yield).

The p-value (0.632. See Table I in appendix) of the MAAR shows no significant evidence of abnormal return and thus no indication of short-term trading (before the ex-date, the p-value of the RTV was 0.822 and after the ex-date 0.493 , suggesting insignificant differences from its theoretical value. This evidence is inconsistent with Nikolaos et al. (2006), who suggested that for the taxable dividend, stock prices fall more than the dividend amount (on the Chinese market).

\subsection{London Stock Exchange}

Table 5. Observes the mean, median, t-test, and Wilcoxon signed-rank test values of the RPR, MAPR, RPD, and MAPD from the LSE

\begin{tabular}{llllll}
\hline & Mean & T-test (mean) & Median & Z-value (median) & Standard deviation \\
\hline RPR & 5.9173 & 3.3795 & 0.9938 & 0.169 & 25.4532 \\
MAPR & 5.9512 & 3.4041 & 0.9879 & 0.158 & 25.4432 \\
RPD & 0.0144 & 2.123 & 0.0129 & -3.69 & 0.0199 \\
MAPD & 0.0146 & 2.2387 & 0.013 & 0 & 0.0201 \\
Dividend yield & 0.0121 & & 0.01 & & 0.0119 \\
\hline
\end{tabular}


The mean of the RPR and MAPR (see Table 5) and associated t-values (z-values) suggests a significant difference between the theoretical and observe values. However, the Wilcoxon (z-value) test accepts the null hypothesis. A higher standard deviation (RPR: 25.4532 and MAPR: 25.4432) supports the results obtained by the t-test. The value of the t-test is also supported by the higher differences between the mean (the RPR and MAPR) and theoretical values. This suggests that stock prices fall more than the dividend amount. We can also explain the stock price behaviour by the mean (median) of the RPD and MAPD. The mean (median) of the RPD and MAPD and related t-values (z-values) rejects the null hypothesis. Comparing the dividend yield with the mean values of the RPD and MAPD, we can conclude that the stock prices drop more than the dividend amount. Too high RPR compare to previous studies (Lasfer and Zenonos, 2003 and Lasfer, 1995) can be due to the investor's expectation to determine the ex-day stock prices and financial instability ${ }^{1}$.

A too-high standard deviation and a too-high value of the RPR and MAPR and associated t-values suggest that the market is experiencing higher volatility compared to the other markets. Further studies are required to find evidence against such volatility in the UK market. We also observe significant evidence of the MAAR (p-value: 0.003. See Table I in Appendix) and of short-term trading (p-value: 0.000) before the ex-dividend day but no indication of short-term trading (p-value: 0.593) after the ex-day. Our study is consistent with Lasfer and Zenonos (2003) regarding the European firms and has documented positive abnormal return from the LSE.

\section{Conclusions}

This paper examines the stock price behaviour of blue-chip stocks on the ex-dividend day. Four capital markets are selected for this study. The reason for this market selection is to examine the behaviour of the most liquid common stock prices on the ex-divided day under different legislation and trading rules. The sample period of this study covers 2005 to 2009, when each capital market experienced a financial crisis and higher volatility. This study also compares Asian, European, and American capital markets and how they react according to the information flow in a financial crisis.

The empirical evidence of the NYSE's and SSE's RPR, MAPR, RPD, and MAPD suggests that stock prices drop by the same amount as the dividend paid on the ex-day. The null hypotheses $\mathrm{H} 5$ and $\mathrm{H} 6$ are true in both markets, suggesting no indication of abnormal return and thus no evidence of short-term trading before and after the ex-day.

The null hypotheses H1, H2, H3, and H4 are rejected by the TSE. And they argued that the stock price drop is less than the dividend amount. The value of the MAAR suggests a statistically significant amount of abnormal return and the value of the RTV supports short-term trading. On the LSE, the values of the RPR, MAPR, RPD, and MAPD demonstrate that stock prices fall more than the dividend amount, which is not consistent with the tax- or transaction-costs hypothesis. Higher standard deviation refers to the higher

\footnotetext{
1 “One after another, LTCM's partners, calling in from Tokyo and London, reported that their markets had dried up. There were no buyers, no sellers. It was all but impossible to maneuver out of large trading bets.” - Wall Street Journal, November 16, 1998.
} 
volatility of the market and the reason for such volatility can be explained by the financial crisis. Most of the FTSE 100 companies are financial institutions. They carried a high risk during the financial crisis and investors were scared to hold the stocks. However, further research is required to find the explanation for such volatility. The value of the MAAR and RTV suggests an abnormal return around the ex-day and thus short-term trading.

\subsection{Limitations and Suggestions for Further Studies}

Even if our study follows common practice in measuring ex-dividend-day price behaviour we acknowledge that there might be some limitations in our research. One limitation can be that our studied period (2005 to 2009) is not be generalizable to other periods and that some of our findings might be an effect of market conditions at that time (even if our analysis of our data does not indicate this). Our analysis is also based on the assumption that blue-chip stocks are a good proxy for capturing ex-dividend-day price behaviour. The limitation with this might be that by limiting the effect of market anomalies (e.g. small firm effects) we are not able to analyse how these potential anomalies might affect ex-dividend-day price behaviour. Hence as a suggestion for future research it might be interesting to study how differences in liquidity and risk (e.g. small versus large stocks) affect ex-dividend-day price behaviour.

Furthermore, further study can present tax, transaction costs and tic size in a same mathematical model by considering the sensitivity of the daily stock prices movement to see how much investors value each variable to calculate the actual ex-day stock prices. In addition, stocks can be classified based on the liquidity and price volatility to find the relationship between the price efficiency of a stock and investors decision around the ex-day which is not considered in this study.

\section{References}

Amihud, Y. (2002). Illiquidity and stock returns: Cross-section and time-series effects. Journal of Financial Markets, 5, 31-56. http://dx.doi.org/10.1016/S1386-4181(01)00024-6

Amihud, Y., \& Mendelson, H. (2012). The Effects of Beta, Bid Ask Spread, Residual Risk, and Size on Stock Returns. The Journal of Finance, 44(2), 479-486. http://dx.doi.org/10.1111/j.1540-6261.1989.tb05067.x

Annaert, J., Buelens, F., Cuyvers, L., De Ceuster, M., Deloof, M., \& De Schepper, A. (2011). Are blue chip stock market indices good proxies for all-shares market indices? The case of the Brussels Stock Exchange 1833-2005. Financial History Review, 18(03), 277-308. http://dx.doi.org/10.1017/S0968565011000187

Bali, Rakesh, Hite, \& Gailen L. (1998). Ex-dividend day stock price behavior: Discreteness or tax-induced clienteles?. Journal of Financial Economics, 47, 127-159. http://dx.doi.org/10.1016/S0304-405X(97)00041-X

Bali, Rakesh, Francis, \& Jack. J. (2011). Further evidence from ex-dividend days. Applied Economics Letters, 19(6), 537-540. http://dx.doi.org/10.1080/13504851.2011.587763

Barclay, Michael J. (1987). Dividends, Taxes and Common Stock Prices: the Ex-dividend 
Day Behavior of Common Stock Prices Before the Income Tax. Journal of Financial Economics, 19, 31-44. http://dx.doi.org/10.1016/0304-405X(87)90027-4

Bell, Leonie, Jenkinson, Tim. (2002). New Evidence on the Impact of Dividend Taxation and on the Identity of the Marginal Tax Investor. Journal of Finance, 57, 1321-1346. http://dx.doi.org/10.1111/1540-6261.00462

Booth, L. D., \& Johnston, D. J. (1984). The Ex-Dividend Day Behavior of Canadian Stock Prices: Tax Changes and Clientele Effects. The Journal of Finance, 39(2), 457-476. http://dx.doi.org/10.1111/j.1540-6261.1984.tb02320.x

Boyd, John H., \& Jagannathan, Ravi. (1994). Ex-Dividend Price Behavior of Common Stocks. Review of Financial Studies, 7, 711-741. http://dx.doi.org/10.1093/rfs/7.4.711

Campbell, J., \& Beranek, A. (1955). Stock Price Behavior on Ex-dividend dates. Journal of Finance, 10, 125-429. http://dx.doi.org/10.1111/j.1540-6261.1955.tb01295.x

Chan, K. C., Chen, N., \& Hsieh, D. A. (1985). An exploratory investigation of the firm size effect. Journal of Financial Economics, 14(3), 451-471. http://dx.doi.org/10.1016/0304-405X(85)90008-X

Chen, H. L., Chow, E. H., \& Shiu, C. Y. (2011). Ex-Dividend Prices and Investor Trades: Evidence from Taiwan. $23^{\text {rd }}$ Australasian Finance and Banking Conference.

Cho, Y. H., \& Engle, R. F. (1999). Time-varying betas and asymmetric effect of news: Empirical analysis of blue chip stocks. NBER Working paper 7330.

Chordia, Tarun, Roll, Richard, \& Subrahmanyam, Avanidhar. (2008). Liquidity and market efficiency. Journal of Financial Economics, 87(2), 249-268. http://dx.doi.org/10.1016/j.jfineco.2007.03.005

Cloyd, C. B., Li, O. Z., \& Weaver, C. D. (2006). Ticks and tax: The joint effects of price discreteness and taxation on ex-dividend returns. Journal of the American Taxation Association, 28(2), 23-46. http://dx.doi.org/10.2308/jata.2006.28.2.23

Dai, Qinglei, \& Rydqvist, Kristian. (2009). Investigation of the costly-arbitrage model of price formation around the ex-dividend day in Norway. Journal of Empirical Finance, 16(4), 582-596. http://dx.doi.org/10.1016/j.jempfin.2009.04.001

Dhatt, Manjeet S., Kim, Yong H., \& Mukherji, Sandip. (1994). Japanese stock price reaction to stock dividend distributions. Pacific-Basin Finance Journal, 2, 43-59. North-Holland. http://dx.doi.org/10.1016/0927-538X(94)90028-0

Dutta, Shantanu, Jog, Vijay M., \& Saadi, Samir.(2004). Re-examination of the Ex-Dividend Day Behaviour of Canadian Stock Prices. Available at SSRN: http://ssrn.com/abstract $=692942$

Eades, K. M., Hess, P. J., \& Kim, E. H. (1984). On interpreting security returns during the ex-dividend period. Journal of Financial Economics, 13(1), 3-34. http://dx.doi.org/10.1016/0304-405X(84)90030-8 
Elton, E.J., \& Gruber, M.J. (1970). Marginal Stockholder Tax Rates and the Clientele Effect. Review of Economics and Statistics, 13, 68-74. http://dx.doi.org/10.2307/1927599

Elton, E.J., Gruber, M., \& Rentzler, J. (1984). The ex-dividend day behavior of stock prices: A re-examination of the clientele effect. A comment. Journal of Finance, 39, 551-56. http://dx.doi.org/10.1111/j.1540-6261.1984.tb02328.x

Fedenia, M., \& Grammatikos, T. (1991). Portfolio rebalancing and the effective taxation of dividends and capital gains following the Tax Reform Act of 1986. Journal of Banking and Finance, 15(3), 501-520. http://dx.doi.org/10.1016/0378-4266(91)90083-X

Franks, J., Mayer, C., \& Rossi, S. (2009). Ownership: evolution and regulation. Review of Financial Studies, 22, 4009-56. http://dx.doi.org/10.1093/rfs/hhn108

Frank, Murray., \& Jagannathan, Ravi. (1998). Why Do Stock Prices drop by less than the Value of the Dividend? Evidence from a Country Without Taxes. Journal of Financial Economics, 47, 161-188. http://dx.doi.org/10.1016/S0304-405X(97)80053-0

Heath, David, C., Jarrow, \& Robert A. (1988). Ex-Dividend Stock Price Behavior and Arbitrage Opportunities. The Journal of Business, 61(1), 95-108. http://dx.doi.org/10.1086/296421

Hearn, B. (2010). Time varying size and liquidity effects in South Asian equity markets: A study of blue-chip industry stocks. International Review of Financial Analysis, 19(4), 242-257. http://dx.doi.org/10.1016/j.irfa.2010.08.007

Jacoby, G., D. Fowler, \& A. Gottesman. (2000). The capital asset pricing model and the liquidity effect: A theoretical approach. Journal of Financial Markets, 3, 69-81. http://dx.doi.org/10.1016/S1386-4181(99)00013-0

Jones, C. (2001). A century of stock market liquidity and trading costs, working paper, Columbia University, New York, NY.

Kalay, A. (1982). The Ex-dividend Day Behavior of Stock Prices: A Re-examination of the Clientele Effect. Journal of Finance, 37, 1059-1070. http://dx.doi.org/10.1111/j.1540-6261.1982.tb03598.x

Kalay, A. (1984). The ex-dividend day behavior of stock prices: A re-examination of the clientele effect: A reply. Journal of Finance, 39, 557-61. http://dx.doi.org/10.1111/j.1540-6261.1984.tb02329.x

Kato, Kato, Loewenstein, Uri. (1995). The Ex-dividends-day Behavior of Stock Prices: The Case of Japan. The Review of Financial Studies, 8, 817-847. http://dx.doi.org/10.1093/rfs/8.3.817

Lakonishok, J., \& Vermaelen, T. (1986). Tax-induced trading around ex-dividend days. Journal of Financial Economics, 287-319. http://dx.doi.org/10.1016/0304-405X(86)90032-2 
Lamdin, Douglas J., \& Hiemstra, Craig. (1993). Ex-Dividend Day Share Price Behavior: Effects of the Tax Reform Act of 1986. The Review of Economics and Statistics, 75, 778-783. http://dx.doi.org/10.2307/2110040

Le Bris, David, Hautcoeur, \& Pierre-Cyrille. (2010). A Challenge to Triumphant Optimists? A Blue Chips Index for the Paris Stock-Exchange (1854-2007). Financial History Review, 17(2), 141-183. http://dx.doi.org/10.1017/S096856501000003X

Litzenberger, R., \& Ramaswamy, K. (1979). The Effect of Personal Taxes and Dividends on Capital Asset Pricing. Journal of Financial Economics, 7, 163-195. http://dx.doi.org/10.1016/0304-405X(79)90012-6

Lasfer, M. Ameziane, \& Zenonos, Maria. (2003). The Tax Impact on the Ex-dividend dates: Evidence from European firms. Cass Business School Research Paper, EFA 2003 Annual Conference Paper 885.

Lasfer, Ameziane M. (1995). Ex-Day Behavior: Tax or Short-Term Trading Effects. The Journal of Finance, 50(3), 875-897. http://dx.doi.org/10.1111/j.1540-6261.1995.tb04040.x

Michaely, R., \& Vila, J. (1996). Trading Volume with Private Valuation: Evidence from the Ex-Dividend Day. Review of Financial Studies, 9, 471-509. http://dx.doi.org/10.1093/rfs/9.2.471

Milonas, Nikolaos T., Travlos, Nickolaos G., \& Xiao, Jason Zezhong. (2006). The Ex-Dividend Day Stock Price Behavior in the Chinese Stock Market. Pacific-Basin Finance Journal, 14(2), 155-174. http://dx.doi.org/10.1016/j.pacfin.2005.06.004

Naranjo, A., Nimalendran, M., \& Ryngaert, M. (2000). Time variation of ex-dividend day stock returns and corporate dividend capture: A re-examination. Journal of Finance, 55, 2357-2372. http://dx.doi.org/10.1111/0022-1082.00290

Poterba, J., \& Summers, L. (1984). New Evidence that Taxes Affect the Valuation of $\begin{array}{llll}\text { Dividends. Journal of } & \text { Finance, } & 39, & 1397-1415 .\end{array}$ http://dx.doi.org/10.1111/j.1540-6261.1984.tb04914.x

Roll, R. (2012). A possible explanation of the small firm effect. The Journal of Finance, 36(4), 879-888. http://dx.doi.org/10.1111/j.1540-6261.1981.tb04890.x

Tetlock, Paul C. (2006). Does Liquidity Affect Securities Market Efficiency?. No 159, Working paper, Regulation2point0. http://EconPapers.repec.org/RePEc:reg:wpaper:159.

Weiss, G., \& Lowe, J. (1988). Dividends don't lie: finding value in blue-chip stocks. Chicago, IL: Longman Financial Services Publishing.

Whitworth, J., \& Rao, R. P. (2010). Do Tax Law Changes Influence Ex-Dividend Stock Price Behavior? Evidence from 1926 to 2005. Financial Management, 39(1), 419-445. http://dx.doi.org/10.1111/j.1755-053X.2010.01078.x 
Appendix I. P-values of the MAAR and RTV

\begin{tabular}{lll}
\hline Market & Measure & P-value \\
\hline \multirow{3}{*}{ NYSE } & MAAR & 0.362 \\
& RTV (-1 to -5$)$ & 0.3 \\
& RTV (1 to 5) & 0.197 \\
\hline \multirow{3}{*}{ TSE } & MAAR & $.000^{* *}$ \\
& RTV (-1 to -5$)$ & $.008^{*}$ \\
& RTV (1 to 5) & 0.27 \\
\hline \multirow{3}{*}{ SSE } & MAAR & 0.632 \\
& RTV (-1 to -5$)$ & 0.822 \\
& RTV (1 to 5) & 0.493 \\
\hline \multirow{2}{*}{ LSE } & MAAR & $.003^{*}$ \\
& RTV (-1 to -5$)$ & $.000^{* *}$ \\
& RTV (1 to 5) & 0.593 \\
\hline
\end{tabular}

Significance levels: $* *$ indicates $\mathrm{p}<0.001, *$ indicates $\mathrm{p}<0.01$. 